\title{
Transcriptional responses of Anopheles gambiae s.s mosquito larvae to chronic exposure of cadmium heavy metal [version
}

\section{1; peer review: 2 approved with reservations]}

\author{
Catherine N. Muturi (D1, Martin K. Rono2,3, Daniel K. Masiga(D4, \\ Francis N. Wachira5, Richard Ochieng ${ }^{6}$, Paul O. Mireji (i) 3,7 \\ ${ }^{1}$ Department of Biochemistry and Molecular Biology, Egerton University, Egerton, Kenya \\ ${ }^{2}$ Pwani University Health and Research Institute, Kilifi, Kenya \\ ${ }^{3}$ Centre for Geographic Medicine Research Coast, Kenya Medical Research Institute, Kilifi, Kenya \\ ${ }^{4}$ Molecular Biology and Biotechnology Unit, International Centre of Insect Physiology and Ecology, Nairobi, Kenya \\ ${ }^{5}$ South Eastern Kenya University, Kitui, Kenya \\ ${ }^{6}$ School of Biological Sciences, University of Nairobi, Nairobi, Kenya \\ ${ }^{7}$ Biotechnology Research Institute, Kenya Agricultural and Livestock Research Organization, Kikuyu, Kenya
}

V1 First published: $22 \operatorname{Dec} 2017,6: 2173$

https://doi.org/10.12688/f1000research.13062.1

Latest published: 25 Jun 2018, 6:2173

https://doi.org/10.12688/f1000research.13062.2

\section{Abstract}

Background: Anopheles gambiae larvae traditionally thrive in nonpolluted environments. We previously documented the presence of the larvae in heavy metal polluted urban aquatic environments and the associated biological cost. The goal of this study was to unravel the molecular dynamics involved in the adaptation of the mosquitoes to the heavy metals.

Methods: Total RNA was extracted from third instar larvae of both cadmium treated populations and untreated control populations. The RNA concentrations were normalized and complementary DNAs were prepared. Then annealing control primer (ACP) technology was applied to establish transcriptional responses in An. gambiae larvae following several generational $(n=90)$ chronic exposures to cadmium. Differentially expressed genes were determined by their differential banding patterns on an agarose gel. Gel extraction and purification was then carried out on the DEGs and these were later cloned and sequenced to establish the specific transcripts.

Results: We identified 14 differentially expressed transcripts in response to the cadmium exposure in the larvae. Most (11) of the transcripts were up-regulated in response to the cadmium exposure and were putatively functionally associated with metabolism, transport and protein synthesis processes. The transcripts included ATP-binding cassette transporter, eupolytin, ribosomal RNA, translation initiation factor, THO complex, lysosomal alphamannosidase, sodium-independent sulfate anion transporter and myotubularin related protein 2 . The down-regulated transcripts were

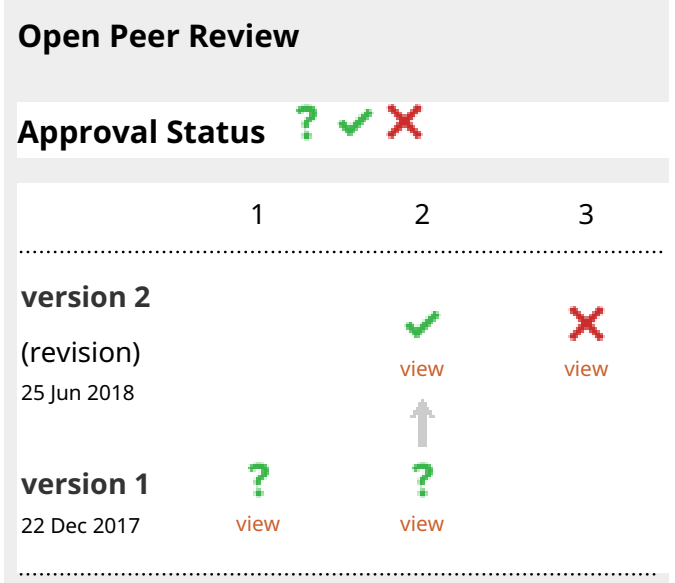

1. David Essumang, University of Cape Coast, Cape Coast, Ghana

2. Shüné V. Oliver $[D$, National Institute for Communicable Diseases, Johannesburg, South Africa

\section{Dick Roelofs ID, Vrije Universiteit}

Amsterdam, Amsterdam, The Netherlands

Any reports and responses or comments on the article can be found at the end of the article. 
functionally associated with signal transduction and proteolytic activity and included Protein G12, adenylate cyclase and endoplasmic reticulum metallopeptidase.

Conclusions: Our findings shed light on pathways functionally associated with the adaptation to heavy metals that can be targeted in integrated vector control programs, and potential An. gambiae larvae biomarkers for assessment of environmental stress or contamination.

\section{Keywords}

Anopheles gambiae larvae, differentially expressed genes, cadmium, heavy metal tolerance

Corresponding author: Catherine N. Muturi (katengambi@gmail.com)

Author roles: Muturi CN: Conceptualization, Data Curation, Formal Analysis, Funding Acquisition, Investigation, Methodology, Supervision, Writing - Original Draft Preparation, Writing - Review \& Editing; Rono MK: Conceptualization, Writing - Review \& Editing; Masiga DK: Conceptualization, Resources, Supervision, Writing - Review \& Editing; Wachira FN: Supervision, Writing - Review \& Editing; Ochieng R: Methodology, Resources; Mireji PO: Conceptualization, Funding Acquisition, Project Administration, Supervision, Writing Review \& Editing

Competing interests: No competing interests were disclosed.

Grant information: Funding for this study was provided by the Department of Research and Extension, Egerton University and the DAAD in-country Scholarship.

The funders had no role in study design, data collection and analysis, decision to publish, or preparation of the manuscript.

Copyright: ( $) 2017$ Muturi CN et al. This is an open access article distributed under the terms of the Creative Commons Attribution License, which permits unrestricted use, distribution, and reproduction in any medium, provided the original work is properly cited. Data associated with the article are available under the terms of the Creative Commons Zero "No rights reserved" data waiver (CC0 1.0 Public domain dedication).

How to cite this article: Muturi CN, Rono MK, Masiga DK et al. Transcriptional responses of Anopheles gambiae s.s mosquito larvae to chronic exposure of cadmium heavy metal [version 1; peer review: 2 approved with reservations] F1000Research 2017, 6:2173 https://doi.org/10.12688/f1000research.13062.1

First published: 22 Dec 2017, 6:2173 https://doi.org/10.12688/f1000research.13062.1 


\section{Introduction}

Heavy metal pollution has become a global environmental problem and severely threatens biological diversity and human health. Our studies on adaptation to heavy metals have documented presence of the mosquitoes in polluted habitats (Mireji et al., 2008) with growing evidence that this adaptation comes at a biological cost to the mosquito (Mireji et al., 2010b). Similar biological costs to adaptations have also been observed elsewhere in Culex pipiens $\mathrm{L}$ responses to cadmium, copper, lead and mercury (El-Sheikh et al., 2010). To date, molecular dynamics underpinning heavy metal tolerance in insects have been tied to transcripts and genes associated functionally with immunity (Sorvari et al., 2007) and defense and repair mechanisms such as glutathione transferases and heat shock proteins (Liao \& Freedman, 1998; Kim et al., 2000; Stohs et al., 2001). We have previously putatively implicated metallothioneins, alpha-tubulin and cytochrome p450 genes associated with defense, repair and pyrethroid metabolism mechanisms in insects with heavy metal tolerance, using single gene assessment approaches with Anopheles gambiae mosquito larvae (Mireji et al., 2010b; Mireji et al., 2006; Musasia et al., 2013). Here, we have emulated $a b$ initio relatively higher throughput annealing control primer (ACP) transcriptional profiling, to identify:

1) Pathways functionally associated with heavy metal adaptation observed in the field and their associated biological costs (Mireji et al., 2008; Mireji et al., 2010b); and

2) Potential An. gambiae larvae biomarkers that can be applied for assessment of environmental stress or contamination.

\section{Methods}

\section{Sample insects}

Anopheles gambiae s.s mosquitoes that had been collected from the Mbita field station (00.025'S, 34.013'E), Homa Bay County in Kenya were used for the study. The colony was kept in the Animal Rearing and Quarantine Unit (ARQU) at the International Centre of Insect Physiology and Ecology (ICIPE), Nairobi, Kenya. Larval stages of Anopheles gambiae s.s. were selected for tolerance to cadmium heavy metal through chronic exposures of Maximun Acceptable Toxicant Concentration (MATC) that had been empirically determined (Mireji et al., 2010a). Cadmium metal tolerant strains and control (untreated) strains of the mosquito were raised separately and in triplicates. All subsequent generations of the mosquito were subjected to chronic exposures of cadmium metal as described in Mireji et al., (2010a). Standard Operating Procedure (SOP) for the rearing of Anopheles mosquitoes was followed for colony maintenance (Ford \& Green, 1972). Cadmium used in our study was applied as Cadmium Chloride $\left(\mathrm{CdCl}_{2}\right)$ 99.99\% pure (Fisher Scientific LLC, Fair Lawn, NJ, U.S.A).

\section{RNA isolation}

Total RNA was extracted from the third instar larvae of experimental and control An. gambiae populations using Trizol
(Invitrogen). Quantification of the extracted RNA was done using the micro-spectrophotometer Genequant pro (Amersham Pharmacia Ltd., Bucks, UK). In addition, DNaseI digestion was carried out to remove any residual DNA that could present in the extracted RNA. Total RNA that was isolated and stored at $-80^{\circ} \mathrm{C}$.

\section{GeneFishing $^{\text {TM }}$ Reverse Transcription}

The total RNA extracted from experimental and control An. gambiae populations were normalized to same concentrations and directly used for the synthesis of first strand complementary DNA (cDNA) using reverse transcriptase (Hwang et al., 2003). Reverse transcription was carried out in a final reaction volume of $20 \mu \mathrm{l}$ containing $2 \mu \mathrm{g}$ of the purified mRNA at $42^{\circ} \mathrm{C}$ for 1.5 hours. The components of the reaction were: $4 \mu \mathrm{l}$ of $5 \mathrm{X}$ reaction buffer (Promega, Madison, WI, U.S.A), $2 \mu$ of $10 \mu \mathrm{mol}$ cDNA synthesis dT-ACP 1 primer (5'- CGTGAATGCTGCGA CTACGATIIIII(T) $\left.)_{18}-3^{\prime}\right)$, $5 \mu$ dNTPS- $2 \mathrm{mM}$ each, $0.5 \mu l$ RNase inhibitor(40U/ $\mu \mathrm{l}$, Promega) and $1 \mu \mathrm{l}$ Moloney murine leukemia virus reverse transcriptase $(200 \mathrm{U} / \mu \mathrm{l}$, Promega). The synthesized first strand cDNA was diluted by adding $80 \mu \mathrm{l}$ ultra-purified water. Storage was at $-20^{\circ} \mathrm{C}$ awaiting PCR procedure.

\section{ACP based- GeneFishing ${ }^{\mathrm{TM}}$ PCR}

Annealing control primer based PCR using the GeneFishing TM DEG kit from Seegene, Seoul, South Korea (Kim et al., 2004), was used to determine differentially expressed genes in the heavy metal treated group and the control population.

Synthesis of the second strand cDNA and PCR was carried out in a single tube. The second strand was synthesized in one cycle of first stage PCR at $50^{\circ} \mathrm{C}$, in a final reaction volume of $20 \mu \mathrm{l}$. The

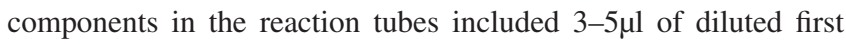
strand cDNA, $1 \mu \mathrm{l} 10 \mathrm{Mm}$ dT-ACP2 reverse primer (5'-CTGTG AATGCTGCGACTACGATIIIII(T) $)_{15}-3^{\prime}$ ), $10 \mu \mathrm{l} 2 \mathrm{x}$ master mix (Seegene, Seoul, South Korea) and $1 \mu \mathrm{l} 10 \mu \mathrm{M}$ arbitrary ACP (forward primer).

PCR procedures for the synthesis of the second strand were completed in one cycle, at $94^{\circ} \mathrm{C}$ for $1 \mathrm{~min}$ then $50^{\circ} \mathrm{C}$ for $3 \mathrm{~min}$ and $72^{\circ} \mathrm{C}$ for $1 \mathrm{~min}$.

The second stage of the PCR protocol consisted of 40 cycles at $94^{\circ} \mathrm{C}$ for $40 \mathrm{~s}, 65^{\circ} \mathrm{C}$ for $40 \mathrm{~s}, 72^{\circ} \mathrm{C}$ for $40 \mathrm{~s}$ and the final extension for $10 \mathrm{~min}$ at $72^{\circ} \mathrm{C}$. $2 \%$ agarose gel electrophoresis with ethidium bromide staining was used for separation of the PCR products.

\section{Gel extraction}

Differentially expressed bands in the control and cadmium exposed population subjected to the same primer set were excised from the agarose gel using a scapel under Ultra Violet illumination. The gel slices were then purified using the QIAquick ${ }^{\circledR}$ gel extraction kit (QIAGEN, Inc., Valencia, CA), following the instructions from the manufacturer. 
Cloning

Gel-purified PCR products were directly cloned into a pGEMT Easy vector (Invitrogen, Carlsbad, CA, USA), using JM109 competent cells. Colonies were grown at $37^{\circ} \mathrm{C}$ for 18 hours on Luria broth agar plates, containing ampicillin, X-gal and IPTG for blue/white colony screening. Cloned plasmids were then purified using the GeneJET ${ }^{\mathrm{TM}}$ Miniprep kit (Fermentus, Thermo Fisher Scientific Inc.), as per the instructions from the manufacturer.

\section{Sequencing}

Sequencing was done with ABI PRISM ${ }^{\circledR} 3100$ Genetic Analyzer (Applied Biosystems, Foster City, CA, USA) using M13 primers. The sequences were edited using VecScreen and BioEdit software. Edited sequences were analyzed by searching for similarities in VectorBase against the Anopheles gambiae PEST strain transcripts sequences, AgamP4.6 geneset using the BLASTn search program (Altschul et al., 1990)

\section{Results}

We successfully implemented the ACP system to identify differentially expressed genes (DEGs) in larvae chronically exposed to cadmium, as previously demonstrated in blastocyst experiments (Cui et al., 2005; Hwang et al., 2004; Hwang et al., 2005). Our differential banding patterns of the cDNA representation of DEGs is summarized in Figure 1. Fourteen DEGs were identified after chronic exposure of An. gambiae larvae to cadmium heavy metal (Table 1). Most (11) of the differentially expressed genes were induced in cadmium exposed relative to the cadmium un-exposed controls. Our BLAST (REF) results revealed that the cadmium induced transcripts were clustered into metabolism (AGAP008584-RA, AGAP001249RA and AGAP009563-RA), transport (AGAP012302-RA and AGAP002638-RA) and protein synthesis (AGAP028915-RA, AGAP004750-RA, AGAP028391-RA, AGAP003870-RA, AGAP028907-RA, AGAP028818-RA and AGAP028899-RA) processes.

Three of the DEGs identified were suppressed in the cadmium exposed larvae and these included AGAP006187-RA, AGAP002262-RA and AGAP003078-RA.

Dataset 1. Dataset 1: Sequence data obtained after sequence analysis using the BioEdit software

http://dx.doi.org/10.5256/f1000research.13062.d187045

The sequences were subsequently taken through a BLAST search. The results of the sequence analysis are shown on the manuscript.

Dataset 2. Dataset 2: Sample of the colony PCR experiment http://dx.doi.org/10.5256/f1000research.13062.d187046

The gel photo of a colony PCR of 20 samples that was carried out after blue/white colony screening using M13 primers.

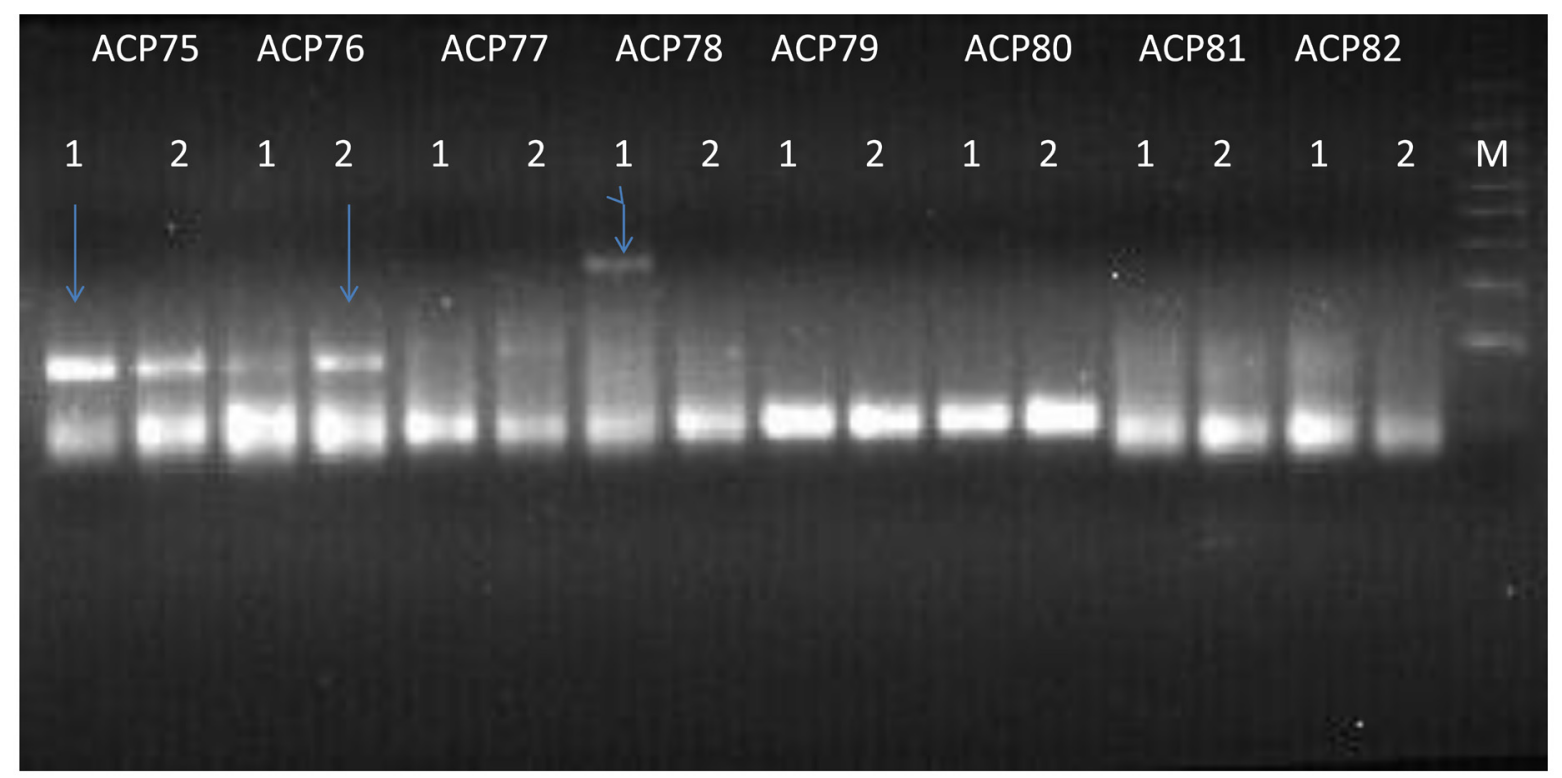

Figure 1. Differential cDNA banding patterns in cadmium treated and control population of mosquito larvae. The arrows indicate the DEGs observed using ACP 75, ACP 76 and ACP 78 primer set. Number 1 represents Cadmium population while 2 represents control population. $M=50 \mathrm{bp}$ molecular marker. High intensity of a band represents an up-regulation of a particular gene in cadmium or control population. 
Table 1. Blastn results from VectorBase. Sequence data obtained was blasted against Anopheles gambiae PEST strain transcript sequences, AgamP4.6 geneset in May 2017.

\begin{tabular}{|c|c|c|c|c|c|}
\hline Gene & Gene name & Description of gene product & E-Value & $\%$ ID & $\begin{array}{l}\text { Expression } \\
\text { pattern }\end{array}$ \\
\hline AGAP002638-RA & $\mathrm{ABCH} 1$ & $\begin{array}{l}\text { ATP-binding cassette transporter } \\
\text { (ABC transporter) family } \mathrm{H} \text { member } 1\end{array}$ & 3 & 77.5 & Up \\
\hline AGAP001249-RA & & Eupolytin & $3 e-31$ & 98.7 & Up \\
\hline AGAP028915-RA & SSU_rRNA_eukaryotic & Eukaryotic small subunit ribosomal RNA & $8 e-79$ & 98.2 & Up \\
\hline AGAP004750-RA & & Translation initiation factor $4 \mathrm{G}$ & 6.4 & 87 & Up \\
\hline AGAP028915-RA & SSU_rRNA_eukaryotic & Eukaryotic small subunit ribosomal RNA & $8 e-78$ & 99.4 & Up \\
\hline AGAP006187-RA & & Protein G12 & 6.8 & 100 & Down \\
\hline AGAP003078-RA & & Endoplasmic reticulum metallopeptidase 1 & 1.5 & 80.6 & Down \\
\hline AGAP028391-RA & Isu rRNA & & $3 e-103$ & 100 & Up \\
\hline AGAP028915-RA & SSU_rRNA_eukaryotic & Eukaryotic small subunit ribosomal RNA & $4 e-49$ & 96.6 & Up \\
\hline AGAP028915-RA & SSU_rRNA_eukaryotic & Eukaryotic small subunit ribosomal RNA & $5 e-81$ & 98.8 & Up \\
\hline AGAP003870-RA & Thoc7 & THO complex subunit 7 & 6.4 & 87 & Up \\
\hline AGAP008584-RA & & Lysosomal alpha-mannosidase & 3.4 & 90.5 & Up \\
\hline AGAP010252-RA & RpL23 & $60 S$ ribosomal protein L23 & $4 e-12$ & 100 & Up \\
\hline AGAP028907-RA & SSU_rRNA_eukaryotic & Eukaryotic small subunit ribosomal RNA & $3 e-06$ & 91.2 & Up \\
\hline AGAP028818-RA & 5_8S_rRNA & 5.8S ribosomal RNA & $3 e-37$ & 98.9 & Up \\
\hline AGAP028899-RA & SSU_rRNA_eukaryotic & Eukaryotic small subunit ribosomal RNA & $2 e-08$ & 100 & Up \\
\hline AGAP009563-RA & & Myotubularin related protein 2 & 0.74 & 91.3 & Up \\
\hline AGAP002262-RA & & Adenylate cyclase 8 & 9.6 & 100 & Down \\
\hline AGAP012302-RA & & $\begin{array}{l}\text { Sodium-independent sulfate anion } \\
\text { transporter }\end{array}$ & 0.36 & 88.9 & Up \\
\hline
\end{tabular}

\section{Discussion}

We identified ATP-binding cassette transporters belonging to the superfamily of membrane proteins that are present in all living organisms (Dean \& Annilo, 2005). They are normally associated with movement of substrates such as amino acids, peptides, sugars, metals, inorganic ions, lipids, lipopolysaccharides and xenobiotics across biological membranes (Dawson \& Locher, 2006; Hollenstein et al., 2007a). The ABC transporters have been shown to affect development, metabolism and insecticide resistance in insects (Borycz et al., 2008; Dow \& Davies, 2006; Ricardo \& Lehmann, 2009; Vache et al., 2007). The silencing of the $\mathrm{ABCH} 1$ gene has been shown to result in the death of larvae and pupae (Guo et al., 2015). Therefore, induction of the ABC transporters may suggest that they are involved in cadmium transport through membranes to reduce toxicity of cadmium metal to the larvae in their environment.

The induction of the eupolytin gene may have a role in the activation of defense molecules. In a study involving the ground beetle Eupolyphaga sinensis, eupolytin-1 gene encoding a protease was shown to be involved in the activation of plasminogen and hydrolysis of fibrinogen (Yang et al., 2011).

Ribosomal genes are involved in protein synthesis and upregulation of the various arrays of ribosomal RNAs in this study, which suggests their role in enhancing the survival of An. gambiae in the heavy metal polluted environment by the transcription and translation of genes which are important in the adaptation of the larvae to xenobiotics.

The nuclear structure referred to as THO complex is usually conserved in all kingdoms, and it has an important role in the packing of pre-mRNA molecules into RNA-protein assemblies which are termed mRNPs (Köhler \& Hurt, 2007). A study carried out recently has shown that the THO complex is required for efficient expression of some genes, ensuring genetic stability thereby preventing transcription-associated recombination (Gewartowski et al., 2012). The expression of the THO complex is suggestive of its role in expressing defense genes that enhance survival of larvae in a Cadmium polluted environment.

Suppression of AGAP006187-RA, AGAP002262-RA and AGAP003078-RA transcripts that included G- Proteins couple receptors to adenylyl cyclase stimulation indicated increasing levels of cAMP and a cascade of events that constitute the signal transduction pathway that drive cellular responses. Metallopeptidases are a ubiquitous and diverse group of enzymes containing both endopeptidases and exopeptidases. Although they vary widely at the sequence, structural, and functional levels, they all require a metal ion for catalytic activity (Rawlings \& Salvesen, 2013). 
The suppression of these important genes involved in signal transduction and proteolytic activity would account for the larval mortality rates that are usually observed in larvae raised in the cadmium heavy metal environment.

Our findings shed light on the adaptation of the An. gambiae mosquito to heavy metals by differentially expressing particular genes in response to a toxicant impact. A study to determine differentially expressed genes in cadmium-exposed sebastes schlegeli unraveled genes related to pathogenesis, extrinsic stresses, and catalytic metabolites (Woo \& Yum, 2014). Previous studies have indicated that metallothionein and $\alpha$-tubulin genes that are present in insects can be used as potential biomarkers (Hare, 1992; Klerks \& Weis, 1987; Mattingly et al., 2001; Roesijadi, 1994). Metallothionein was assessed through C. quinquefasciatus mosquito larvae for Copper, Cadmium and Zinc aquatic environmental levels (Sarkar et al., 2004). Therefore, the genes identified might be useful in the development of potential biomarkers that can be used to assess the level of environmental pollution of heavy metal origin in An. gambiae mosquitoes.

\section{Conclusions}

We were able to identify genes that are differentially expressed due to chronic exposure of An. gambiae larvae to cadmium metal using the ACP-based PCR method. However, application of more sensitive techniques like those used in proteomics would generate more data.

\section{Data availability}

Dataset 1: Sequence data obtained after sequence analysis using the BioEdit software. The sequences were subsequently taken through a BLAST search. The results of the sequence analysis are shown on the manuscript. DOI, 10.5256/ f1000research.13062.d187045 (Muturi et al., 2017a).

Dataset 2: Sample of the colony PCR experiment. The gel photo of a colony PCR of 20 samples that was carried out after blue/white colony screening using M13 primers. DOI, 10.5256/ f1000research.13062.d187046 (Muturi et al., 2017b).

\section{Competing interests}

No competing interests were disclosed.

\section{Grant information}

Funding for this study was provided by the Department of Research and Extension, Egerton University and the DAAD in-country Scholarship.

The funders had no role in study design, data collection and analysis, decision to publish, or preparation of the manuscript.

\section{Acknowledgements}

We hereby wish to acknowledge the following individuals for their contribution to this work:

The Head of the Capacity Building Department at ICIPE, for granting us permission to carry out this work in their Molecular and Biotechnology unit.

The Director of the Research and Extension Department at Egerton University.

The DAAD team for the financial support, which enabled this work to be completed.
Altschul SF, Gish W, Miller W, et al.: Basic local alignment search tool. $J$ Mol Biol. 1990; 215(3): 403-410.

PubMed Abstract | Publisher Full Text

Borycz J, Borycz JA, Kubow A, et al.: Drosophila ABC transporter mutants white, brown and scarlet have altered contents and distribution of biogenic amines in the brain. J Exp Biol. 2008; 211(Pt 21): 3454-3466.

PubMed Abstract | Publisher Full Text

Cui XS, Shin MR, Lee KA, et al:: Identification of differentially expressed genes in murine embryos at the blastocyst stage using annealing control primer system. Mol Reprod Dev. 2005; 70(3): 278-287.

PubMed Abstract | Publisher Full Text

Dawson RJ, Locher KP: Structure of a bacterial multidrug ABC transporter. Nature. 2006; 443(7108): 180-185.

PubMed Abstract | Publisher Full Text

Dean M, Annilo T: Evolution of the ATP-binding cassette (ABC) transporter superfamily in vertebrates. Annu Rev Genomics Hum Genet. 2005; 6: 123-142. PubMed Abstract | Publisher Full Text

Dow JA, Davies SA: The Malpighian tubule: rapid insights from post-genomic biology. J Insect Physiol. 2006; 52(4): 365-378.

PubMed Abstract | Publisher Full Text

El-Sheikh TMY, Fouda MA, Hassan MI, et al.: Toxicological Effects of Some Heavy Metal lons on Culex pipiens L. (Diptera: Culicidae). Acad J biolog Sci. 2010; 2(1): 63-76.

Reference Source
Ford HR, Green E: Laboratory rearing of Anopheles albimanus. Mosq News. 1972; 32: 509-513.

Reference Source

Gewartowski K, Cuéllar J, Dziembowski A, et al.: The yeast THO complex forms a 5-subunit assembly that directly interacts with active chromatin. Bioarchitecture. 2012; 2(4): 134-137.

PubMed Abstract | Publisher Full Text | Free Full Text

Guo Z, Kang S, Zhu X, et al:: The novel ABC transporter ABCH1 is a potential target for RNAi-based insect pest control and resistance management. SCi Rep. 2015; 5: 13728.

PubMed Abstract | Publisher Full Text | Free Full Text

Hare L: Aquatic insects and trace metals: bioavailability, bioaccumulation, and toxicity. Crit Rev Toxicol. 1992; 22(5-6): 327-369.

PubMed Abstract | Publisher Full Text

Hollenstein K, Frei DC, Locher KP: Structure of an ABC transporter in complex with its binding protein. Nature. 2007a; 446(7132): 213-216.

PubMed Abstract | Publisher Full Text

Hwang KC, Cui XS, Park SP, et al.: Identification of differentially regulated genes in bovine blastocysts using an annealing control primer system. $\mathrm{Mol}$ Reprod Dev. 2004; 69(1): 43-51.

PubMed Abstract | Publisher Full Text

Hwang IT, Kim YJ, Kim SH, et al.: Annealing control primer system for improving specificity of PCR amplification. Biotechniques. 2003; 35(6): 1180-1184.

PubMed Abstract 
Hwang KC, Lee HY, Cui XS, et al.: Identification of maternal mRNAs in porcine parthenotes at the 2-cell stage: a comparison with the blastocyst stage. $\mathrm{Mol}$ Reprod Dev. 2005; 70(3): 314-323.

PubMed Abstract | Publisher Full Text

Kim KA, Chakraborti T, Goldstein GW, et al.: Immediate early gene expression in PC12 cells exposed to lead: Requirement for protein kinase C. J Neurochem. 2000; 74(3): 1140-1146.

PubMed Abstract | Publisher Full Text

Kim YJ, Kwak Cl, Gu YY, et al:: Annealing control primer system for identification of differentially expressed genes on agarose gels. Biotechniques. 2004; 36(3): 424-6, 428, 430 passim

PubMed Abstract

Klerks PL, Weis JS: Genetic adaptation to heavy metals in aquatic organisms: a review. Environ Pollut. 1987; 45(3): 173-205.

PubMed Abstract | Publisher Full Text

Köhler A, Hurt E: Exporting RNA from the nucleus to the cytoplasm. Nat Rev Mol Cell Biol. 2007; 8(10): 761-73.

PubMed Abstract | Publisher Full Text

Liao VH, Freedman JH: Cadmium-regulated genes from the nematode Caenorhabditis elegans. Identification and cloning of new cadmium-responsive genes by differential display. J Biol Chem. 1998; 273(48): 31962-31970. PubMed Abstract | Publisher Full Text

Mattingly KS, Beaty BJ, Mackie RS, et al.: Molecular cloning and characterization of a metal responsive Chironomus tentans alpha-tubulin cDNA. Aquat Toxicol.

2001; 54(3-4): 249-260.

PubMed Abstract | Publisher Full Text

Mireji PO, Keating J, Hassanali A, et al.: Biological cost of tolerance to heavy metals in the mosquito Anopheles gambiae. Med Vet Entomol. 2010b; 24(2): 101-107.

PubMed Abstract | Publisher Full Text | Free Full Text

Mireji PO, Keating J, Hassanali A, et al.: Expression of metallothionein and alpha-tubulin in heavy metal-tolerant Anopheles gambiae sensu stricto

(Diptera: Culicidae). Ecotoxicol Environ Saf. 2010a; 73(1): 46-50.

PubMed Abstract | Publisher Full Text | Free Full Text

Mireji PO, Keating J, Hassanali A, et al.: Heavy metals in mosquito larval habitats in urban Kisumu and Malindi, Kenya, and their impact. Ecotoxicol Environ Saf. 2008; 70(1): 147-153.

PubMed Abstract | Publisher Full Text | Free Full Text

Mireji PO, Keating J, Kenya E, et al:: Differential Induction of Proteins in Anopheles gambiae sensu stricto (Diptera: Cullicidae) Larvae in Response to Heavy Metal Selection. Int J Trop Insect Sci. 2006; 26(4): 214-226.

PubMed Abstract | Publisher Full Text | Free Full Text

Musasia FK, Isaac AO, Masiga DK, et al.: Sex-specific induction of CYP6 cytochrome P450 genes in cadmium and lead tolerant Anopheles gambiae. Malar J. 2013; 12: 97.

PubMed Abstract | Publisher Full Text | Free Full Text

Muturi CN, Rono MK, Masiga DK, et al.: Dataset 1 in: Transcriptional responses of Anopheles gambiae s.s mosquito larvae to chronic exposure of cadmium heavy metal. F1000Research. 2017a.

Data Source

Muturi CN, Rono MK, Masiga DK, et al:: Dataset 2 in: Transcriptional responses of Anopheles gambiae s.s mosquito larvae to chronic exposure of cadmium heavy metal. F1000Research. 2017b.

Data Source

Rawlings ND, Salvesen GS: Handbook of Proteolytic Enzymes. Elsevier, San Diego, Calif, USA. 2013

Reference Source

Ricardo S, Lehmann R: An ABC transporter controls export of a Drosophila germ cell attractant. Science. 2009; 323(5916): 943-946.

PubMed Abstract | Publisher Full Text | Free Full Text

Roesijadi G: Metallothionein induction as a measure of response to meta exposure in aquatic animals. Environ Health Perspect. 1994; 102(Suppl 12) 91-95.

PubMed Abstract | Free Full Text

Sarkar S, Duttagupta AK, Mal TK: Effects of heavy metals on population growth and metallothionein gene expression in the mosquito Culex quinquefasciatus, from Calcutta, India. Environ Pollut. 2004; 127(2): 183-193.

PubMed Abstract | Publisher Full Text

Sorvari J, Rantala LM, Rantala MJ, et al.: Heavy metal pollution disturbs immune response in wild ant populations. Environ Pollut. 2007; 145(1): 324-328.

PubMed Abstract | Publisher Full Text

Stohs SJ, Bagchi D, Hassoun E, et al.: Oxidative mechanisms in the toxicity of chromium and cadmium ions. J Environ Pathol Toxicol Oncol. 2001; 20(2): 77-88. PubMed Abstract | Publisher Full Text

Vache C, Camares O, Cardoso-Ferreira MC, et al: A potential genomic biomarker for the detection of polycyclic aromatic hydrocarbon pollutants: multidrug resistance gene $\mathbf{4 9}$ in Drosophila melanogaster. Environ Toxicol Chem. 2007; 26(7): 1418-1424.

PubMed Abstract | Publisher Full Text

Woo S, Yum S: Differentially Expressed Genes in Cadmium-Exposed Sebastes Schlegeli Using Dd-Pcr. App Sci Report. 2014; 6(2): 62-66.

Reference Source

Yang $\mathrm{H}$, Wang $\mathrm{Y}$, Xiao $\mathrm{Y}$, et al:: A bi-functional anti-thrombosis protein containing both direct-acting fibrin(ogen)olytic and plasminogen-activating activities. PLoS One. 2011; 6(3): e17519.

PubMed Abstract | Publisher Full Text | Free Full Text 


\section{Open Peer Review}

\section{Current Peer Review Status: ? ?}

\section{Version 1}

Reviewer Report 29 May 2018

https://doi.org/10.5256/f1000research.14161.r34199

(C) 2018 Oliver S. This is an open access peer review report distributed under the terms of the Creative Commons Attribution License, which permits unrestricted use, distribution, and reproduction in any medium, provided the original work is properly cited.

\section{Shüné V. Oliver}

Centre for Emerging, Zoonotic and Parasitic Diseases Centre for Emerging, Zoonotic and Parasitic Diseases, National Institute for Communicable Diseases, Johannesburg, South Africa

This manuscript is technically sound, and presents a worthwhile body of research. I would recommend accepting. However, there is one major correction that must be made before accepting. Please give details about the assessment of RNA integrity. Without this, the other results are not valid, so please detail about your confirmation of RNA integrity post extraction.

Is the work clearly and accurately presented and does it cite the current literature? Yes

Is the study design appropriate and is the work technically sound?

Yes

Are sufficient details of methods and analysis provided to allow replication by others? Yes

If applicable, is the statistical analysis and its interpretation appropriate? Not applicable

Are all the source data underlying the results available to ensure full reproducibility? Partly

Are the conclusions drawn adequately supported by the results?

Yes

Competing Interests: No competing interests were disclosed.

I confirm that I have read this submission and believe that I have an appropriate level of 


\section{expertise to confirm that it is of an acceptable scientific standard, however I have significant reservations, as outlined above.}

\section{Author Response 11 Jun 2018}

Catherine Ngambi, Egerton University, Egerton, Kenya

Thanks so much for your positive review of the manuscript.

I am sorry, I had not given the data about the RNA integrity but had only stated that I had

quantified the extracted RNA using the microspectrophotometer genequant pro.

I have revised the manuscript and have indicated the quantification results and the equipments used.

To estimate RNA purity, the ratio of the Absorbance contributed by the RNA to the Absorbance of the contaminants is calculated. The acceptable ratios for purity or typical requirements for A260/A280 ratios are 1.8-2.2.

The samples that were use for the downstream application were those that met the purity criteria of 1.8-2.2, that is the ratios for A260/A280.

Therefore, the revised document now contains these details.

Kindest Regards,

Catherine.

Competing Interests: No competing interests.

Reviewer Report 29 January 2018

\section{https://doi.org/10.5256/f1000research.14161.r29393}

(C) 2018 Essumang D. This is an open access peer review report distributed under the terms of the Creative Commons Attribution License, which permits unrestricted use, distribution, and reproduction in any medium, provided the original work is properly cited.

\section{David Essumang}

Department of Chemistry, University of Cape Coast, Cape Coast, Ghana

The main work is outside my expertise and I was struggling to make some meaningful contribution. The bulk of the work is in molecular experimentation and I have limited knowledge in their methods. However, my major concern with the entomological aspect is that the authors did not show how long (the number of generations) the mosquitoes were exposed to the heavy metal during the selection. This would be helpful if someone wants to repeat the work.

Furthermore, the study did not show the impact of the biomarkers identified in the development, 
enzyme activities and insecticide resistance of the mosquitoes used for the study.

Is the work clearly and accurately presented and does it cite the current literature? Yes

Is the study design appropriate and is the work technically sound?

Yes

Are sufficient details of methods and analysis provided to allow replication by others? Partly

If applicable, is the statistical analysis and its interpretation appropriate?

I cannot comment. A qualified statistician is required.

Are all the source data underlying the results available to ensure full reproducibility? Partly

Are the conclusions drawn adequately supported by the results?

Partly

Competing Interests: No competing interests were disclosed.

Reviewer Expertise: Environmental Scientist

I confirm that I have read this submission and believe that I have an appropriate level of expertise to confirm that it is of an acceptable scientific standard, however I have significant reservations, as outlined above.

Author Response 02 Feb 2018

Catherine Ngambi, Egerton University, Egerton, Kenya

Thanks so much for you review on my article. I appreciate.

I wanted to respond to the question raised about the number of generations that mosquitoes were exposed to cadmium heavy metal. As stated in the Abstract its for 90 generations.

Kindest regards,

Catherine.

Competing Interests: No competing interests were disclosed. 
The benefits of publishing with F1000Research:

- Your article is published within days, with no editorial bias

- You can publish traditional articles, null/negative results, case reports, data notes and more

- The peer review process is transparent and collaborative

- Your article is indexed in PubMed after passing peer review

- Dedicated customer support at every stage

For pre-submission enquiries, contact research@f1000.com 